\title{
Chronic constipation and treatment options (Review)
}

\author{
MAGDY EL-SALHY ${ }^{1,3}$, RUNE SVENSEN ${ }^{2}$, JAN GUNNAR HATLEBAKK ${ }^{3}$, \\ ODD-HELGE GILJA ${ }^{3}$ and TRYGVE HAUSKEN ${ }^{3}$ \\ ${ }^{1}$ Section for Gastroenterology, Department of Medicine, Stord Hospital, Stord 5416; ${ }^{2}$ Section for Surgical Gastroenterology, \\ Haukeland University Hospital, Bergen 5504; ${ }^{3}$ Section for Gastroenterology, Department of Clinical Medicine, \\ University of Bergen, Bergen 5020, Norway
}

Received May 21, 2013; Accepted October 23, 2013

DOI: $10.3892 / \mathrm{mmr} .2013 .1770$

\begin{abstract}
Chronic constipation (CC) is a highly prevalent heterogeneous disorder. Although $\mathrm{CC}$ is not known to be associated with the development of serious disease or with excess mortality, it considerably reduces the patients quality of life. In addition, it represents an economic burden to patients and society. The majority of patients with $\mathrm{CC}$ successfully manage the disorder by dietary management and the use of laxatives. Patients with functional CC (slow-transit and non-slow transit constipation) do not respond to laxatives and are a small fraction of the total population complaining of constipation. Regardless of the low number of these patients, the intractability of their symptoms causes psychological and social stress and greatly impairs their quality of life. Furthermore, these patients consume a disproportionate quantity of medical resources. It appears that these patients have a disturbance in the serotonin transmission system, which results in a cascade of alterations in a number of gut neuroendocrine hormones/transmitters. The effect of prucalopride, a serotonin receptor agonist, in this category of patients appears to be not only a pharmacological prokinetic action, but also a correction of a pre-existing disturbance. Linaclotide, a member of the guanylin peptide family, binds to the ligand-binding region of guanylate cyclase- $\mathrm{C}$ on the luminal surface of gastrointestinal epithelia resulting in increased fluid secretion. This drug has also been found to be effective for the treatment of functional CC. In addition, biofeedback and sacral nerve stimulation are effective in the treatment of CC caused by pelvic floor disorders.
\end{abstract}

Correspondence to: Professor Magdy El-Salhy, Section for Gastroenterology, Department of Medicine, Stord Hospital, 64 Tysevegen, Stord 5416, Norway

E-mail: magdy.el-salhy@helse-fonna.no

Key words: guanylin peptide, functional constipation, linaclotide, pruclopride, receptor agonist, serotonin

\section{Contents}

1. Introduction

2. Definition and types of constipation

3. Possible mechanisms for functional constipation

4. Treatment options

5. Conclusion

\section{Introduction}

Chronic constipation (CC) is a highly prevalent heterogeneous disorder. The prevalence of $\mathrm{CC}$ varies based on how the disorder is defined and whether CC is self-reported or based on criteria (1-5) (Fig. 1). The prevalence rates for females are almost double those for males. CC is not known to be associated with the development of serious disease or with excess mortality rate. However, CC considerably reduces the quality of life to the same degree or more severe than impairments caused by a number of other chronic diseases, including arthritis, asthma or coronary artery disease (6-9). $\mathrm{CC}$ is commonly associated with anxiety and depression worldwide (10-12).

In addition to the increased morbidity caused by $\mathrm{CC}$, it is an economic burden to the patients and society. Significant economic costs in $\mathrm{CC}$ arise from direct and indirect costs. The direct costs are associated with evaluation and treatment and the indirect costs are caused by missing school or work (absenteeism) or not being as productive at school or work as usual (presenteeism). CC led to 6.3 million patient visits in the US in $2004(13,14)$. A large survey study found that the annual health care costs for patients with CC were US\$7522 per patient, $\sim 50 \%$ higher compared with patients with irritable bowel syndrome (IBS; US\$5049 per patient) (11). The long-term direct medical costs of CC are double those of controls over a 15-year period (US\$63,591 vs. \$24,529) (15). In England, 14 million prescriptions were issued for laxatives per year at a cost of $£ 60$ million (1).

\section{Definition and types of constipation}

Constipation is a complex symptom that may be clinically grouped into infrequent bowel movements ( $<3$ per week) and difficult defecation, including straining at defecation, hard or lumpy stools, sensation of incomplete evacuation, sensation of 




Figure 1. Prevalence of constipation in various countries.

blockage or anorectal obstruction and manual manoeuvres to defecation.

As mentioned previously, patients with $\mathrm{CC}$ are a heterogonous group and may be roughly divided into 3 groups: i) Constipation in the elderly and cancer patients; ii) constipation associated with neuromuscular diseases and iii) functional constipation.

Constipation in the elderly and cancer patients constitutes the majority of CC patients. Neither motility disturbances in the gastrointestinal tract or abnormalities in the gut neuroendocrine system have been described to be associated with aging (16-18). It appears that constipation in the elderly is caused primarily by co-morbidity and the side effects of drugs, particularly those used against cardiovascular diseases. In cancer patients, constipation is caused mainly by opiates.

Patients with neuromuscular diseases, including Parkinson's disease, multiple sclerosis and amyotrophic lateral sclerosis suffer from chronic constipation, which is treated differently.

Functional CC comprises idiopathic chronic slow transit constipation and severe forms of IBS. A number of gastroenterologists, including the authors, believe that they are variants of the same disorder (19).

\section{Possible mechanisms for functional constipation}

A number of abnormalities in the neuroendocrine system (NES) of the gut have been observed in slow transit and non-slow transit (IBS-constipation?) (20-30). The gut NES is a local regulatory system, that controls numerous functions of the gastrointestinal tract, including motility, secretion, absorption, gut microcirculation, local immune defence and cell proliferation. It consists of two parts: i) Endocrine cells spread between the epithelial cells of the mucosa facing the gut lumen and ii) peptidergic, serotonergic and nitric-oxide-containing nerves of the enteric nervous system in the gut wall. The gut NES is operated by a large number of bioactive messengers that exert their effects via endocrine, paracrine and neuroendocrine modes of action or by synaptic signalling $(31,32)$. The different components of this system interact and integrate with each other and with the afferent and efferent nerve fibres of the central nervous system $(33,34)$.

In slow and non-slow transit constipation low colonic serotonin and peptide YY (PYY) cell densities and low serotonin content have been observed $(24,26,30,33)$ (Figs. 2 and 3). Serotonin activates the submucosal sensory branch of the enteric nervous system $(32,34)$, which conveys sensations to the central nervous system that are likely to generate the sensation of abdominal pain/discomfort. Furthermore, serotonin controls gastrointestinal motility and chloride secretion via interneurons and motor neurons $(31,34)$. PYY stimulates the absorption of water and electrolytes and is a major regulator of the 'ileal brake'. Furthermore, PYY inhibits prostaglandin E2 and vasoactive intestinal polypeptides, which stimulate intestinal fluid secretion $(32,34)$. Administration of PYY inhibits diarrhoea in experimental mouse models by reducing intestinal fluid secretion and slowing colonic transit $(32,34)$. It appears that functional $\mathrm{CC}$ patients have a disturbance in the serotonin transmission system, which causes a cascade of changes in a number of gut neuroendocrine hormones/transmitters, the most important of which is PYY.

\section{Treatment options}

The European guidelines recommend a treatment algorithm for CC (Fig. 4) (35). The drugs used for the treatment of constipation are summarized in Table I.

Non-pharmacological and changes in life style are the first approaches in the management of mild and moderate constipation. Guidance of diet management with an emphasis on an increase in soluble fibre intake appears to be effective in patients with mild and moderate constipation (35). Based on clinical experience and circumstantial evidence, physicians recommend exercise for $\mathrm{CC}$ patients. The physical activity effects on $\mathrm{CC}$ patients have previously been attributed to promoting overall wellbeing. However, physical activity has been found recently to increase gastrointestinal transit (36-39). The increased gastrointestinal motility has been attributed to vagus stimulation and/or 


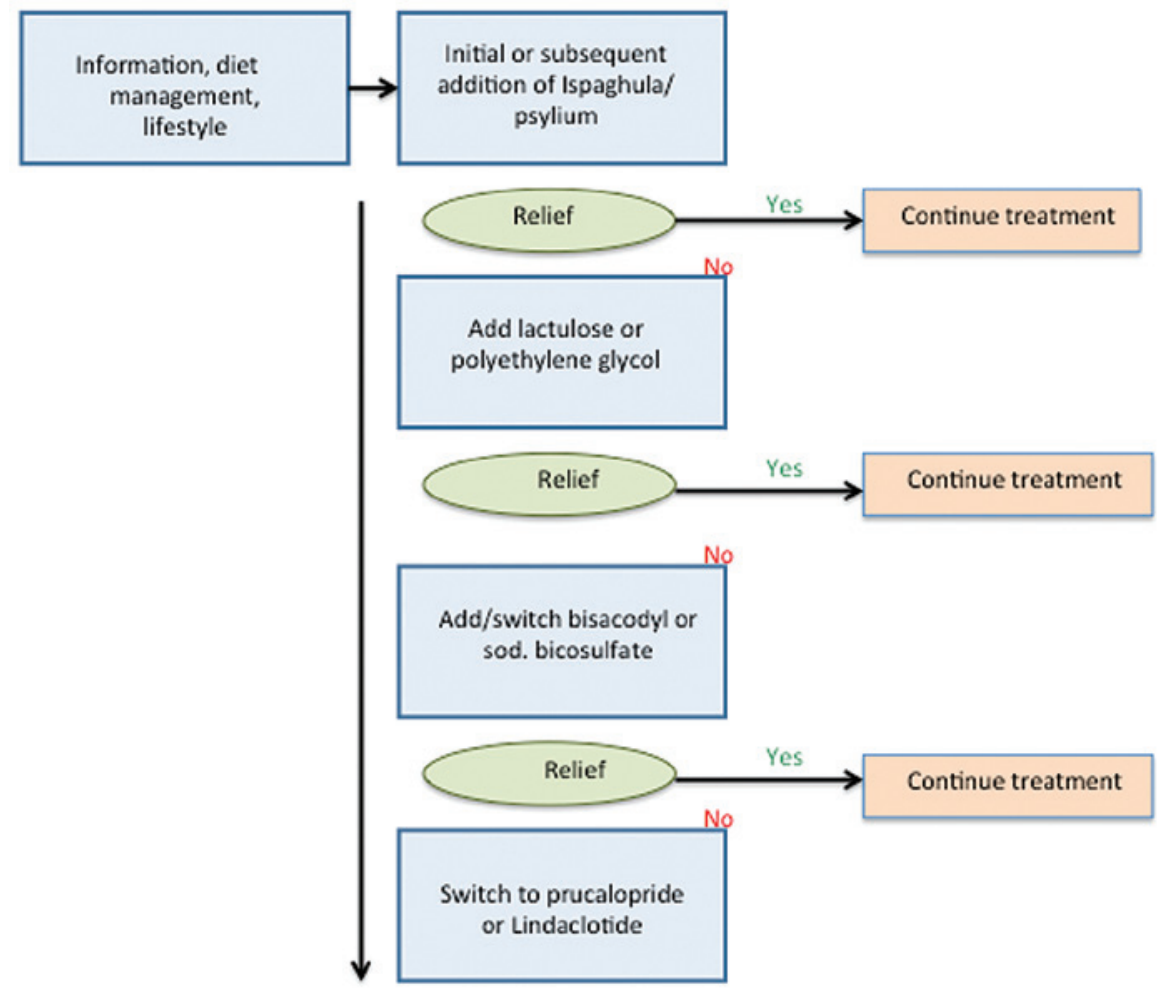

Figure 2. Treatment algorithm used in Norway for chronic constipation.
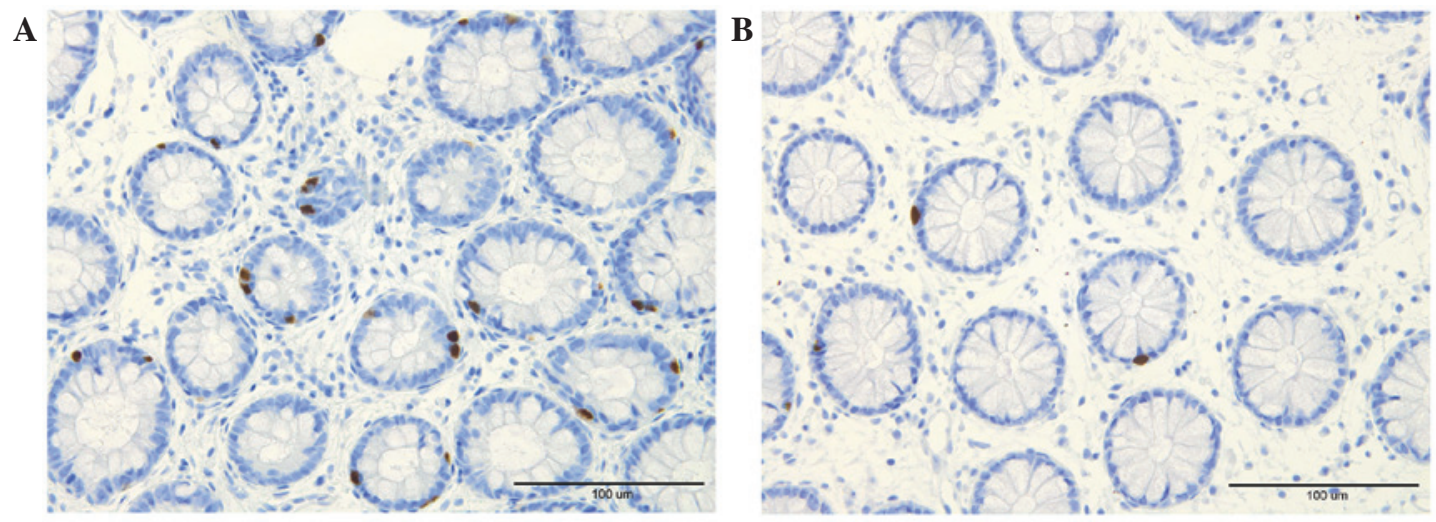

Figure 3. Serotonin immunoreactive cells in the colon of a subject who underwent colonoscopy due to gastrointestinal bleeding, where the cause of bleeding was identified as angiodysplasia (A) and in a patient with slow transit constipation (B).
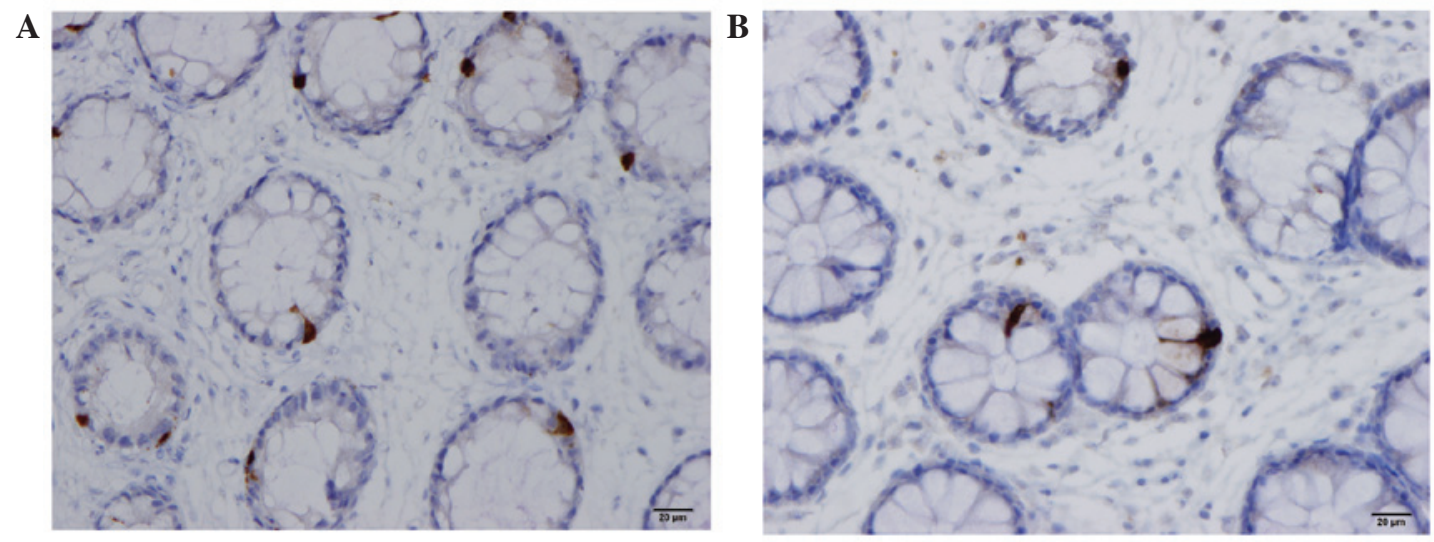

Figure 4. PYY in the colon of a subject who underwent colonoscopy due to gastrointestinal bleeding, where the cause of bleeding was identified as haemorrhoids (A) and in a patient with irritable bowel syndrome with constipation as a predominant symptom (B). PYY, Polypeptide YY. 
Table I. The most common types of drugs used for the treatment of patients with chronic constipation.

\begin{tabular}{|c|c|c|c|}
\hline Drug class & Generic name & Comments & Dose \\
\hline Bulking agents & $\begin{array}{l}\text { Psyllium } \\
\text { Ispaghula }\end{array}$ & $\begin{array}{l}\text { Effective } \\
\text { Effective }\end{array}$ & $\begin{array}{l}25-30 \mathrm{~g} \text { daily in divided doses } \\
3.5 \mathrm{~g} \text { one to three times daily }\end{array}$ \\
\hline Osmotic laxative & $\begin{array}{l}\text { Polyethylene glycol } \\
\text { Lactulose }\end{array}$ & $\begin{array}{l}\text { Effective } \\
\text { Unpalatable taste } \\
\text { Effective } \\
\text { May cause bloating, } \\
\text { flatulence and cramping }\end{array}$ & $17 \mathrm{~g}$ in $237 \mathrm{ml}$ solution daily \\
\hline Stimulant laxatives & $\begin{array}{l}\text { Bisacodyl } \\
\text { Natrium bicosulfate }\end{array}$ & $\begin{array}{l}\text { Effective, but the effects subside with time, } \\
\text { can cause cramping }\end{array}$ & $\begin{array}{l}\text { 5-20 mg daily } \\
5-10 \mathrm{mg} \text { daily }\end{array}$ \\
\hline Emollient laxative & $\begin{array}{l}\text { Mineral oil } \\
\text { Glycerine suppositories }\end{array}$ & $\begin{array}{l}\text { Effective } \\
\text { Effective } \\
\text { Initiates evacuation by distending the rectum }\end{array}$ & $\begin{array}{l}5-10 \mathrm{~cm}^{3} \text { daily } \\
\text { On demand }\end{array}$ \\
\hline $\begin{array}{l}\text { Prokinetic and } \\
\text { prosecretory agents }\end{array}$ & $\begin{array}{l}\text { Pruclopride } \\
\text { Linaclotide }\end{array}$ & $\begin{array}{l}\text { Effective. May cause headache, } \\
\text { nausea, abdominal pain and diarrhoea. } \\
\text { These adverse events occur within the first } 24 \mathrm{~h} \\
\text { of treatment and are short lived } \\
\text { Effective } \\
\text { Diarrhea is the most common side effect }\end{array}$ & $\begin{array}{l}2 \mathrm{mg} \text { daily } \\
290 \mu \mathrm{g} \text { daily }\end{array}$ \\
\hline
\end{tabular}

decreased blood flow to the gut, which leads to an increase in important gastrointestinal hormone release (39). Probiotic intake has also been shown to improve CC symptoms depending on the preparation used and a number of products appear to be more effective than others (40-44). The bacteria that have been proven to be effective in this aspect are Bifidobacterium infantis 35624, Bifidobacterium lactis DN-173-010, Lactobacillus plantrum, Lactobacillus rhamnosus, Lactobacillus acidophilus and Streptococcus faecium (41-44). The mechanism that appears to underlie this improvement is the ability of these bacteria to reduce the number of sulphite-reducing Clostridia spp., which is known to produce gas upon the fermentation of nutrients. This may contribute to improvements in flatulence, bloating and abdominal distension in CC patients (42). Combining diet management, regular exercise and probiotics intake has been found to be effective in reducing the symptoms and improving the quality of life in CC patients with mild and moderate symptoms (45).

In the elderly, concomitant drug use should be assessed and drugs that potentially cause constipation should be discontinued, when possible. Constipation in the elderly and in cancer patients is treated successfully by using one or more of the following bulking agents; polyethylene glycol, lactulose, sodium bicosulphate and bisacodyl. Probiotic intake reduces the side effects of lactulose and fibres. $\mathrm{CC}$ in patients with neuromuscular diseases is successfully treated with polyethylene glycol.

Patients with functional $\mathrm{CC}$ do not respond to any of the laxatives mentioned previously. They are a small fraction of the total population complaining of constipation (46). Regardless of the low number of these patients, the intractability of their symptoms causes psychological and social stress and greatly impairs their quality of life. Furthermore, they consume a disproportionate quantity of medical resources. The treatment options for these patients are prucalopride, linaclotide, biofeedback and sacral nerve stimulation.

Prucalopride is a highly selective serotonin 5HT4 receptor agonist that has been shown to stimulate gut motility (47). It has been observed to be effective in the treatment of $\mathrm{CC}$ that does not respond to laxatives (47-51). Furthermore, it is safe for use in the elderly who commonly suffer from cardiovascular diseases (47-51). As mentioned previously, patients with CC have low serotonin content in the large intestine and it is possible that the effects of prucalopride, a serotonin receptor agonist in this category of patients is not only a pharmacological prokinetic effect, but also a correction of a pre-existing defect in serotonin.

Linaclotide is a member of the guanylin peptide family and similar to endogenous peptide hormones, guanylin and uroguanylinhas have been shown to bind to the ligand binding region of guanylate cyclase-C on the luminal surface of gastrointestinal epithelia, resulting in increased fluid secretion (52). Moreover, linaclotide has been observed to accelerate gastrointestinal transit (52) and has been found to be effective in the treatment of functional CC.

Biofeedback and sacral nerve stimulation have a limited availability and content of biofeedback treatment varies among centers. These treatments are effective in constipation caused by pelvic floor disorders, but the author's observations and recently published reports showed that this treatment is not effective in functional constipation (53).

\section{Conclusion}

$\mathrm{CC}$ is a common gastrointestinal disorder with different aethiology. It markedly reduces the patient's quality of life and is 
an economic burden to the patients and society. The majority of patients are treated successfully with changes in life style, bulking agents or other laxatives. Patients with functional $\mathrm{CC}$ who do not respond to the treatment with laxatives may be treated with prucaloprid or linaclotide. Patients with $\mathrm{CC}$ caused by pelvic floor disorders may be successfully treated by biofeedback or sacral nerve stimulation

\section{References}

1. Woodward S: Assessment and management of constipation in older people. Nurs Older People 24: 21-26, 2012.

2. Pare P: The approach to diagnosis and treatment of chronic constipation: suggestions for a general practitioner. Can J Gastroenterol 25 Suppl B: 36B-40B, 2011.

3. Lacy BE, Levenick JM and Crowell M: Chronic constipation: new diagnostic and treatment approaches. Therap Adv Gastroenterol 5: 233-247, 2012.

4. Peppas G, Alexiou VG, Mourtzoukou E and Falagas ME: Epidemiology of constipation in Europe and Oceania: a systematic review. BMC Gastroenterol 8: 5, 2008.

5. Sanchez MI and Bercik P: Epidemiology and burden of chronic constipation. Can J Gastroenterol 25 Suppl B: 11B-15B, 2011

6. Irvine EJ, Ferrazzi S, Pare P, Thompson WG and Rance L: Health-related quality of life in functional GI disorders: focus on constipation and resource utilization. Am J Gastroenterol 97: 1986-1993, 2002.

7. Sun SX, Dibonaventura M, Purayidathil FW, Wagner JS, Dabbous $\mathrm{O}$ and Mody R: Impact of chronic constipation on health-related quality of life, work productivity, and healthcare resource use: an analysis of the National Health and Wellness Survey. Dig Dis Sci 56: 2688-2695, 2011.

8. Everhart JE and Ruhl CE: Burden of digestive diseases in the United States part II: lower gastrointestinal diseases. Gastroenterology 136: 741-754, 2009.

9. Sandler RS, Everhart JE,Donowitz M, et al: The burden of selected digestive diseases in the United States. Gastroenterology 122 1500-1511, 2002.

10. Cheng C, Chan AO, Hui WM and Lam SK: Coping strategies, illness perception, anxiety and depression of patients with idiopathic constipation: a population-based study. Aliment Pharmacol Ther 18: 319-326, 2003.

11. Mason HJ, Serrano-Ikkos E and Kamm MA: Psychological state and quality of life in patients having behavioral treatment (biofeedback) for intractable constipation. Am J Gastroenterol 97: 3154-3159, 2002.

12. Haug TT, Mykletun A and Dahl AA: Are anxiety and depression related to gastrointestinal symptoms in the general population? Scand J Gastroenterol 37: 294-298, 2002.

13. Martin BC, Barghout V and Cerulli A: Direct medical costs of constipation in the United States. Managed care interface 19: 43-49, 2006.

14. Nyrop KA, Palsson OS, Levy RL, et al: Costs of health care for irritable bowel syndrome, chronic constipation, functional diarrhoea and functional abdominal pain. Aliment Pharmacol Ther 26: 237-248, 2007

15. Choung RS, Branda ME, Chitkara D, et al: Longitudinal direct medical costs associated with constipation in women. Aliment Pharmacol Ther 33: 251-260, 2011.

16. McCrea GL, Miaskowski C, Stotts NA, Macera L and Varma MG: Pathophysiology of constipation in the older adult. World J Gastroenterol 14: 2631-2638, 2008.

17. Sandström O and El-Salhy M: Ageing and endocrine cells of human duodenum. Mech Ageing Dev 108: 39-48, 1999

18. Sandström O and El-Salhy M: Human rectal endocrine cells and aging. Mech Ageing Dev 108: 219-226, 1999.

19. Quigley EM: Prucalopride: safety, efficacy and potential applications. Therap Adv Gastroenterol 5: 23-30, 2012.

20. Krishnamurthy S, Schuffler MD, Rohrmann CA and Pope CE II: Severe idiopathic constipation is associated with a distinctive abnormality of the colonic myenteric plexus. Gastroenterology 88 26-34, 1985.

21. Schouten WR, ten Kate FJ, de Graaf EJ, Gilberts EC, Simons JL and Klück P: Visceral neuropathy in slow transit constipation: an immunohistochemical investigation with monoclonal antibodies against neurofilament. Dis Colon Rectum 36: 1112-1117, 1993.
22. Wedel T, Roblick UJ, Ott V, et al: Oligoneuronal hypoganglionosis in patients with idiopathic slow-transit constipation. Dis Colon Rectum 45: 54-62, 2002

23. Park HJ, Kamm MA, Abbasi AM and Talbot IC: Immunohistochemical study of the colonic muscle and innervation in idiopathic chronic constipation. Dis Colon Rectum 38: 509-513, 1995.

24. El-Salhy M and Norrgård O: Colonic neuroendocrine peptide levels in patients with chronic idiopathic slow transit constipation. Ups J Med Sci 103: 223-230, 1998.

25. Sjölund K, Ekman R, Akre F and Lindner P: Motilin in chronic idiopathic constipation. Scand J Gastroenterol 21: 914-918, 1986.

26. Sjölund K, Fasth S, Ekman R, et al: Neuropeptides in idiopathic chronic constipation (slow transit constipation). Neurogastroenterol Motil 9: 143-150, 1997.

27. Preston DM, Adrian TE, Christofides ND, Lennard-Jones JE and Bloom SR: Positive correlation between symptoms and circulating motilin, pancreatic polypeptide and gastrin concentrations in functional bowel disorders. Gut 26: 1059-1064, 1985.

28. Tomita R, Fujisaki S, Ikeda T and Fukuzawa M: Role of nitric oxide in the colon of patients with slow-transit constipation. Dis Colon Rectum 45: 593-600, 2002.

29. Tomita R, Tanjoh K, Fujisaki S, Ikeda T and Fukuzawa M: Regulation of the enteric nervous system in the colon of patients with slow transit constipation. Hepatogastroenterol 49: 1540-1544, 2002.

30. El-Salhy $\mathrm{M}$, Norrgård $\mathrm{O}$ and Spinnell S: Abnormal colonic endocrine cells in patients with chronic idiopathic slow-transit constipation. Scand J Gastroenterol 34: 1007-1011, 1999.

31. El-Salhy M, Ostgaard H, Gundersen D, Hatlebakk JG and Hausken T: The role of diet in the pathogenesis and management of irritable bowel syndrome (Review). Int J Mol Med 29: 723-731, 2012.

32. El-Salhy M, Seim I, Chopin L, Gundersen D, Hatlebakk JG and Hausken T: Irritable bowel syndrome: the role of gut neuroendocrine peptides. Front Biosci (Elite Ed) 4: 2783-2800, 2012.

33. El-Salhy M, Gundersen D, Ostgaard H, Lomholt-Beck B, Hatlebakk JG and Hausken T: Low densities of serotonin and peptide YY cells in the colon of patients with irritable bowel syndrome. Dig Dis Sci 57: 873-878, 2012

34. El-Salhy M, Gundersen D, Hatlebakk JG and Hausken T (eds): Irritable Bowel Syndrome: Diagnosis, Pathogenesis and Treatment Options. 1st edition. Nova Science Publishers, Inc., New York, 2012.

35. Tack J, Müller-Lissner S, Stanghellini V, et al: Diagnosis and treatment of chronic constipation - a European perspective. Neurogastroenterol Motil 23: 697-710, 2011.

36. Ostgaard H, Hausken T, Gundersen D and El-Salhy M: Diet and effects of diet management on quality of life and symptoms in patients with irritable bowel syndrome. Mol Med Rep 5: 1382-1390, 2012.

37. Johannesson E, Simrén M, Strid H, Bajor A and Sadik R: Physical activity improves symptoms in irritable bowel syndrome: a randomized controlled trial. Am J Gastroenterol 106: 915-922, 2011.

38. Chey WD and Rai J: Exercise and IBS: no pain, no gain. Gastroenterology 141: 1941-1943, 2011.

39. Strid H, Simrén M, Störsrud S, Stotzer PO and Sadik R: Effect of heavy exercise on gastrointestinal transit in endurance athletes. Scand J Gastroenterol 46: 673-677, 2011.

40. Wang Y, Kondo T, Suzukamo Y, Oouchida Y and Izumi S: Vagal nerve regulation is essential for the increase in gastric motility in response to mild exercise. Tohoku J Exp Med 222: 155-163, 2010.

41. Whelan K: Probiotics and prebiotics in the management of irritable bowel syndrome: a review of recent clinical trials and systematic reviews. Curr Opin Clin Nutr Metab Care 14: 581-587, 2011.

42. Whorwell PJ: Do probiotics improve symptoms in patients with irritable bowel syndrome? Therap Adv Gastroenterol 2: 37-44, 2009.

43. Spiller R: Review article: probiotics and prebiotics in irritable bowel syndrome. Aliment Pharmacol Ther 28: 385-396, 2008.

44. Aragon G, Graham DB, Borum M and Doman DB: Probiotic therapy for irritable bowel syndrome. Gastroenterol Hepatol (NY) 6: 39-44, 2010.

45. El-Salhy M, Lillebø E, Reinemo A, Salmelid L and Hausken T: Effects of a health program comprising reassurance, diet management, probiotics administration and regular exercise on symptoms and quality of life in patients with irritable bowel syndrome. Gastroenterology Insights 2: 21-26, 2010. 
46. Spiller RC: Upper gut dysmotility in slow-transit constipation: is it evidence for a pan-enteric neurological deficit in severe slow transit constipation? Eur J Gastroenterol Hepatol 11: 693-696, 1999.

47. Quigley EM, Vandeplassche L, Kerstens R and Ausma J: Clinical trial: the efficacy, impact on quality of life, and safety and tolerability of prucalopride in severe chronic constipation - a 12-week, randomized, double-blind, placebo-controlled study. Aliment Pharmacol Ther 29: 315-328, 2009.

48. Tack J,CamilleriM, Chang L, etal: Systematic review: cardiovascular safety profile of 5-HT(4) agonists developed for gastrointestinal disorders. Aliment Pharmacol Ther 35: 745-767, 2012.

49. Ke M, Zou D, Yuan Y, et al: Prucalopride in the treatment of chronic constipation in patients from the Asia-Pacific region: a randomized, double-blind, placebo-controlled study. Neurogastroenterol Motil 24:999-e541, 2012.
50. Camilleri M, Van Outryve MJ, Beyens G, Kerstens R, Robinson P and Vandeplassche L: Clinical trial: the efficacy of open-label prucalopride treatment in patients with chronic constipation - follow-up of patients from the pivotal studies. Aliment Pharmacol Ther 32: 1113-1123, 2010.

51. Camilleri M, Beyens G, Kerstens R, Robinson P and Vandeplassche L: Safety assessment of prucalopride in elderly patients with constipation: a double-blind, placebo-controlled study. Neurogastroenterol Motil 21: 1256-e1117, 2009.

52. Johnston JM, Shiff SJ and Quigley EM: A review of the clinical efficacy of linaclotide in irritable bowel syndrome with constipation. Curr Med Res Opin 29: 149-160, 2013.

53. Emmanuel A: Current management strategies and therapeutic targets in chronic constipation. Therap Adv Gastroenterol 4: 37-48, 2011. 